\section{Peaceful warriors and warring peacemakers}

Neil Cooper

$\mathrm{T}$ he concern of this article is with the legacies that war economies and the discourses surrounding war economies leave for peacebuilding after conflict. In particular, it will be suggested that the concentration on certain pariah actors and certain goods serves to obscure both the breadth of actors and the underlying structures that drive war economies.

\section{Conflict, trade, and war}

The trade in resources such as diamonds, drugs and even people has become one of the defining features of the "new wars" of the post-Cold War era. Indeed, there is now a burgeoning political economy school that highlights the rational calculations underpinning even vicious wars, and the sophisticated networks established by warring factions to exploit the shadow markets created by local wars in a globalized world. In so doing, the literature potentially offers an alternative to crude "ancient ethnic hatreds" explanations of conflicts such as those in the Balkans or to the notion of "new barbarism" used to explain what has been described as "the coming anarchy" in weak African states.

Discourses emphasizing the primordial nature of current conflicts effectively disguise the complicity of the developed world in creating the conditions for conflict

Conflict entrepreneurs are as sensitive to changes in their framework as any other business.

This alternative in itself is significant for peacemaking and peacekeeping because discourses emphasizing the primordial nature of current conflicts effectively disguise the complicity of the developed world in creating the conditions for conflict and thus the moral responsibility this brings to work for peace. Indeed, the characterization of contemporary conflicts as war between erratic primitives habituated to violence has encouraged some to argue that we should simply "give war a chance" as peacemaking between such actors is pointless prior to victory or war exhaustion. In contrast, the political economy characterization of local warlords as rational agents plugged into regional and global trade networks not only suggests such conflict entrepreneurs might be pressured into peace and peace building but that they are as sensitive to a change in their framework of economic incentives as any other business. For instance, when the price of the mineral coltan, used in the manufacture of mobile phones, rose exponentially on world markets a few years ago, this led to the coltan equivalent of a gold rush as the warring factions in the Democratic Republic of the Congo (DRC) turned to mining the mineral to finance war.

Recognition of this sensitivity to external market forces has led to the emergence of a control agenda over the issue of conflict trade, most notably with respect to the trade in conflict diamonds. For instance, the UN imposed embargoes on diamonds from UNITA in Angola and the RUF in Sierra Leone. Sanctions have also been imposed on the export of rough diamonds from Liberia in recognition of its role as a conduit for RUF diamonds. In addition, states, industry and NGOs have come together in the Kimberley process to develop an international certification scheme for rough diamonds. ${ }^{1}$ The declared aim is to guarantee that rough diamonds traded around the world are not conflict diamonds. Although elements of the scheme are still under discussion, implementation began by the end of 2002 .

The control agenda and peace

Despite initiatives on diamonds, the discourse on war economies and the emerging control agenda has been marked by a number of features that have served to circumscribe its application to post-conflict peace building.

The discourse has largely been focused on the role conflict trade plays in the inception and perpetuation of war. This may appear an odd statement to make, as war economies might seem by definition to be creatures of conflict. This is precisely the point however. The process by which war economies have been problematized has served to mark them out as exceptional and distinct rather than reflective of broader responses to both globalization and the structural violence inherent in North-South relations. Indeed, conflict trade tends to be represented as a form of criminalized deviancy perpetuated by violent leaders or warlords whose interests exist outside of, and in opposition to those of the broader society they inhabit. Such trade is thus demarcated as an aberration grafted onto decent society by the conditions of war, leading to the concomitant assumption that the conclusion of war and the defeat (or reincorporation) of the deviant will inevitably create conditions for cessation of the trade - especially with a little dose of good governance and neo-liberalism.

In contrast, while war economies may well be a vehicle for predatory warlords, they can also serve important economic, social, and welfare functions, even amidst (and sometimes because of) high levels of violence. For instance, the FARC (Revolutionary Armed Forces of Colombia) has developed a sophisticated social safety net that includes a minimum wage for coca pickers and pensions for retired guerrillas. Similarly, the coltan boom in the DRC led to an influx of miners, which in turn created a local trade in prostitutes and treatments for sexually transmitted diseases - both paid for in coltan. Post-conflict strategies that emphasize 
criminalization/eradication without also establishing new mechanisms of profit and power for these communities are more likely to embed recidivism than to build peace.

Furthermore, narratives on the informal economy also undergo a shift in the transition from war to peace - while war economies are depicted as serving economic and political interests, albeit of homicidal warlords, war economies in peace are constructed as a problem of “ordinary,” de-politicized criminality or corruption. In other words, they are depicted as a problem of a different order and of a different kind. In reality, war economies not only reflect social transformations that amount to the creation of alternative systems of profit, power, and protection, but ones that have their roots in pre-conflict economic structures and which either persist in, or adapt to, the conditions of post-conflict peace. Indeed, at the extremes, the persistence of war economies after war may simply result in a homicidal peace in which post-war killings equal or exceed those in war. ${ }^{2}$

\begin{abstract}
War economies, then, do not simply disappear as one deals with criminals or in response to the application of good governance initiatives after peace. Instead, they mutate in relation to the conditions of peace, often evolving to feed off the new dynamics created.
\end{abstract}

War economies, then, do not simply disappear as one deals with criminals or in response to the application of good governance initiatives after peace. Instead, they mutate in relation to the conditions of peace, often evolving to feed off the new dynamics created. At the extreme, as in the case of UNITA and the RUF, the ability to continue illicit trade means peace spoilers retain the wherewithal to resume war if peace seems to be delivering fewer benefits. Even where peace agreements hold, the influence that war elites establish over key economic sectors during conflict can reverberate through the process of state reconstruction and peace building, effectively perpetuating war economies or the economic dominance of war elites, under conditions of non-war. This has been the case in both Bosnia and Cambodia.

Even where action, in the form of regulation and policing, is taken to address the legacies of conflict trade in peace, the effect can be to either create new opportunities for illicit trade or simply to act as a spur to innovation. For instance, the transition from war to peace in Sierra Leone is supported by a national Certificate of Origin Scheme designed to guarantee that only government-authorized diamonds are traded abroad and to implement the embargo on Liberian diamonds noted above. However, the effect of sanctions on Liberia has meant that the problem of RUF diamonds being routed through the country has been reversed, with Liberian diamonds now passing through dealers in Sierra Leone and Cote d'Ivoire who specialize in laundering Liberian rough. Indeed, according to some dealers, the introduction of a certification scheme in Sierra Leone has made it easier to launder diamonds as it obviates the need for complicated smuggling through other countries. Furthermore, insurgents in Guinea and particularly the LURD (Liberians United for Reconciliation and Democracy) in Liberia are now reportedly using diamonds and other commodities to fund their activities. It is also the case that illicit smuggling simply for tax avoidance purposes remains endemic across the region.

External intervention in the process of peacemaking and peace building can also create new opportunities for shadow trade that pre-existing war elites can exploit, often drawing on the same global networks previously utilized to fund war. First, peace negotiations often focus on the agents of violence. The interests of civil society are consequently treated as an afterthought, considered only once the parameters of post-war power and political economy have been established in agreements with warlords or militaries whose main concern is maintaining influence, rather than transforming the status quo. At the extreme, peace agreements can simply entrench a warlord political economy, as occurred in Sierra Leone where the peace accord of 1999 allocated responsibility for the country's diamond trade to Foday Sankoh, the leader of the rebel RUF. Sankoh simply used his position to facilitate personal business deals and the RUF continued to mine diamonds.

Second, aid workers and peacekeepers create a new and distorted local political economy that may even be antithetical to long-term development. A good example is the creation of a market in which translators and drivers are paid more than teachers and engineers. They may also create shadow markets too - most notably in the sex trade that arises to service the internationals. In some cases, intervention may even contribute to a political economy that promotes conflict. In Somalia, control over food aid and the provision of security guards to nongovernmental organizations (NGO's) gave local warlords a material interest in preserving the insecurity that fueled the trade in both.

Third, the very policies advocated by external agencies may create new economic opportunities for war elites while simultaneously undermining the goals that the policies aim to achieve. For instance, the application of neo-liberalism provides new openings for war elites to enrich themselves through control of privatization processes, while also fostering the illicit economy as an alternative to welfarism.

\section{Pariahs and peace}

A further issue that the emerging control agenda on conflict trade raises for peace building relates to the way its articulation both reflects and reinforces narratives of conflict. However, such narratives can skew perceptions of the challenges involved in the transformation of war economies in peace.

There are two aspects to this problem. First, while the literature on war economies inevitably highlights the complicity of first world businesses in fueling conflict, the concentration on certain pariah actors (UNITA, RUF, Charles Taylor) risks pinning 
the blame for conflict on avaricious warlords (as opposed to say avaricious Western businesses or arms exporting states). Indeed, some studies, e.g. Collier's work emphasizing greed rather than grievance as the explanation for civil conflict, have elevated this bias to the status of economic fact. Thus, rather like the ancient ethnic hatreds thesis the literature purports to reject, much of the work in this field risks putting war down to the uncivilized barbarians outside the zone of peace rather than the actors inside.

The UN General Assembly's December 2000 resolution defines that diamonds sold by UNITA are conflict diamonds but not those sold by the Angolan government.

2000. This defines them as rough diamonds which are used by rebel movements to finance their military activities, including attempts to undermine or overthrow legitimate governments.

Thus, diamonds sold by UNITA are conflict diamonds but those sold by the Angolan government are not. This of course follows much the same logic that governs the sale of arms to states: that sovereign (and legitimate) governments have a right to self-defense. However, the definition of rebels (as opposed to say the "freedom fighters" of Afghanistan's Northern Alliance or in Northern Iraq) and the definition of legitimate states is more a function of the narratives constructed around individual conflicts than a reflection of objective reality or of the scale of resource predation. For instance, while Liberia and the RUF have experienced embargoes on conflict goods, the resource predation of Uganda and Rwanda (both in favor with the UK and U.S.) in the DRC has gone unpunished. Similarly, it has only been Charles Taylor and the RUF that have been targeted for international opprobrium over the trade in conflict diamonds from Sierra Leone. In contrast, a relative silence has been constructed around the trade conducted by peacekeepers, pro-government forces in Sierra Leone, and wider society in both Sierra Leone and Liberia.

This has implications for policy after war. There is a concomitant risk that narratives of past resource predation will have a detrimental influence on policy toward the political economy of present peace building. In particular, there is a danger that external patrons will consider action against local or regional "rogues" as sufficient to transform war economies, while the activities of other actors continue to be overlooked or constructed as a problem of a lesser order. In Sierra Leone, for instance, while the diamond embargoes on the RUF and Liberia remain (quite rightly) in place, it is equally the case that the current government of Sierra Leone is widely viewed as corrupt by its citizens. This view is reinforced by the recent closed door decisions to grant large and long-term diamond and oil concessions to foreign companies, by the fact that four senior members are themselves reportedly engaged in illicit diamond mining, and by the use of diplomatic bags to smuggle diamonds.

Third, just as the activities of certain actors may be highlighted in the dominant narratives of conflict developed by external actors, so the trade in particular goods - most notably drugs and diamonds - has become the focus of concern. Again, this has implications for the strategies adopted in peace as many conflicts are in fact characterized by illicit activity across a range of sectors. For instance, an estimated 60-70 percent of the Taliban's \$100 million war budget was actually derived from revenue earned through the smuggling of fuel, consumer, and durable goods rather than opium.

To date at least, there has been a tendency to particularize both the range of actors who engage in conflict trade and the conflict goods deemed worthy of control. One consequence of this is to encourage a "drugs and thugs" cum pariah goods control agenda which effectively obscures attention to the broader political economy that conflict leaves as its legacy.

\section{Control-lite and prophylactic control}

While this agenda certainly hampers the development of effective peace building strategies, it nevertheless serves important functions in the maintenance of the neoliberal order. First, it keeps the responsibility for conflict neatly pinned on criminal leaders. At worst it extends complicity to the venality of specific individuals and companies in the developed world - who can usually cop a plea bargain. In contrast, the criminal effects of a global system that produces the permissive conditions (structural violence and underdevelopment) for much conflict are provided with an alibi.

Explaining war by reference to avaricious warlords obviates the need to explain why substantial portions of society often participate in the shadow trade that supports war economies or to consider the role of poverty in fueling conflict. In sub-Saharan Africa for instance, the site of forty percent of the armed conflicts in the world, nearly half the population live on less than a dollar a day. The average life expectancy of an African citizen is just 48 years - and falling, while the region's share of world trade (excluding South Africa) fell from three percent in the 1950's to 1.2 percent in the mid-1990's. ${ }^{3}$ Between 1997 and 1999 the combined annual index of free market prices for primary commodities, which represent 80 percent of Africa's export earnings, fell by 25 percent. In this context shadow trade, whether in war or peace, represents the means by which those excluded from or relegated to the periphery of the global economy reincorporate themselves into its workings. For instance, in Angola as little as 10 percent of the country's gross national product (GNP) is thought to be produced through the formal economy while in Afghanistan an 
estimated 80 percent of the economy and 30-50 percent of the population has been involved in some aspect of the drugs trade.

Second, the focus on specific commodities or specific actors allows a judicious mix of "control-lite" and "prophylactic control." Control-lite reflects an approach toward conflict trade in goods for the formal economy that leaves large swathes of business free of formal restrictions - whether it be oil in Angola, coltan in the DRC, or timber in Liberia. At best, control has been confined to voluntary initiatives by industry. The one exception is the issue of conflict diamonds. Even here, proposals for an international certification scheme for diamonds have been constrained by industry interests, with the result that the putative regime lacks teeth. For instance, monitoring and enforcement is by self-regulation and some elements of the system are merely "recommended" or subject to voluntary participation. This has led the U.S. General Accounting Office to note that, as currently envisaged, the scheme may simply "provide the appearance of control, while still allowing conflict diamonds to enter the legitimate diamond trade."

Crucially "control-lite" avoids addressing the role of neo-liberalism in fostering inequality and conflict. In contrast, deep control would require intervention in the global economy to redress inequalities between North and South (and indeed within the North). For instance, Oxfam has called for an international commodities institution to tackle the crisis in commodity prices. This might also address the conflict trade in such goods. Deep control would also require the creation of regimes able to place meaningful sanctions on firms and states that benefit from conflict trade. Ironically, such sanctions tend to be most often available only when actors offend the principles of free trade. For instance, in 1999 British Airways was fined $£ 4$ million for breaching EU competition rules (by offering extra commission to travel agents who increased BA ticket sales). In contrast, funding war economies merely tends to result in the kind of PR problems that the oil firm Talisman has experienced over its operations in Sudan or that Sabeena has over its transportation of coltan from the DRC.

The same neo-liberal drive for free trade, open borders and deregulation that forms the basis for prosperity and relative peace in the Northern hemisphere provides the permissive conditions for the trade of conflict entrepreneurs.

By focusing on rogues or individual companies (or even individuals within individual companies), “control lite” also largely obviates the need to address the contradictions in neo-liberalism, most notably the fact that the same neo-liberal drive for free trade, open borders, and deregulation that forms the basis for prosperity and relative peace in the North also provides the permissive conditions for the deterritorialized network trade of conflict entrepreneurs. This is brought into sharp relief on those rare occasions when attempts are made to control conflict trade. Thus, the putative international certification scheme for conflict diamonds has been hampered by disagreement over how to reconcile the requirement to cease trading with nonparticipants and by agreements such as GATT, which enshrine free trade.

Prophylactic control, in contrast, tends to address the problems that war and informal economies export to the zones of peace in the West - e.g., drugs, asylum seekers, sex workers. The emphasis here has been on creating a cordon sanitaire around the developed world rather than addressing the structural causes of such trade. The aim is to prevent transmission (except by video camera) of the "virus of disorder" to the developed world. For instance, the UN Drug Control Program in Central Asia has largely focused on interdiction, border control, and strengthening of law enforcement agencies. Ironically, however, the emphasis on "sticks rather than carrots” has not only been criticized as hypocritical (the domestic strategies of many developed states do in fact emphasize harm reduction) but also as ineffective.

\section{Conclusion}

Both discourse and policy on war economies has tended to treat them as separate and distinct from both the pre and post-conflict economy. In reality, war economies tend to represent simply more violent versions of the neo-patrimonialism and external trade relations that characterize many developing states both before and after conflict. Assuming that peace will inevitably resolve the legacies that war economies leave behind is thus a forlorn hope. In addition, the discourse and control agenda surrounding conflict trade has been constructed in a way that negatively affects peace building. In particular, the focus on certain pariahs or specific conflict goods tends to understate the complexity of war economies and the social function they serve - features that persist into peace.

There is a need instead to address the underlying structural and social dynamics that war economies both reflect and create. In particular, it is important to redress the exclusion and peripheralization in the global economy that shadow trade is a response to. In addition, civil society needs to be empowered so that it can play a role in monitoring and influencing the political economy of peace building. Last but not least, if a political economy of peace building is to be constructed, attention needs to be paid to deconstructing the narratives of war and war economies that have developed, as these often produce a skewed and partial truth which hinders the development of effective policy and thus also inhibits the transformation of war economies in peace. 
(C) www.epsjournal.org.uk - Vol. 1, No. 1 (2006)

\section{Notes}

Neil Cooper was, at the time of writing, senior lecturer in politics at the University of Plymouth, UK. He is now at the University of Bradford.

1. See David Gold's article, in this volume, on conflict diamonds.

2. Cooper, N. and M. Pugh. 2002. "Security Sector Transformation in Post-Conflict Societies.” The Conflict, Security and Development Group Working Paper Series, No. 5. London: Centre for Defence Studies.

3. Oxfam, 2002. Africa at the Crossroads: Time to Deliver. Oxfam Briefing Paper No. 19. Oxford: Oxfam. 